\title{
Echa konfederacji barskiej w okolicznościowej literaturze politycznej lat 1772-1775
}

Barbara Wolska 


\section{Barbara Wolska}

\section{Echa konfederacji barskiej w okolicznościowej literaturze politycznej lat 1772-1775}

$\mathrm{O}$ kolicznościowa literatura polityczna czasów pierwszego rozbioru i sejmu delegacyjnego skupia się w kręgu trzech podstawowych bloków tematycznych:

I. Probem rozbioru,

II. Ideologiczne uzasadnienia i uwarunkowania nowej polityki,

III. Życie polityczne czasów sejmu delegacyjnego.

W tekstach zgromadzonych wokół problemu rozbioru, tj. traktujących pierwszy rozbiór ako temat centralny, nawiązania do czasów konfederacji barskiej są następujące:

1. odwołania do toczonych wówczas walk i do sytuacji kraju znękanego zniszczeniami Nojennymi;

2. osąd bieżących wydarzeń rozbiorowych z perspektywy mentalności charakterystycznej lla okresu barskiego;

3. publikacje utworów barskich oraz ich parafrazy, dostosowywane do aktualnych okoiczności;

4. ocena osobistości politycznych ważnych dla ruchu barskiego (przede wszystkim zaś: ienatorów wywiezionych do Rosji podczas sejmu repninowskiego w 1767 r., a uwolnionych Niosną 1773 r.).

Zanim omówię kolejno przykłady tego rodzaju nawiązań, pragnę przypomnieć powsze'hne prawie niezrozumienie groźby rozbioru w 1. 1770-1771, także w sferach najlepiej nawet solitycznie zorientowanych i doświadczonych (np. Familii). Zaś w 1772 r. dopiero w kwietiu i w maju wiadomość o trójporozumieniu rozbiorczym dotarła do niektórych tylko człon- 
ków cieszyńskiej Generalności i działaczy konfederacji oraz do Stanisława Augusta ${ }^{1}$. Wiadomości tej jednak nie rozpowszechniano, by nie rozszerzać nastrojów defetystycznych (np. pozostali członkowie Generalności poznali ją dopiero w czerwcu t. r.), choć wrogie akcje przeprowadzane w pierwszej polowie 1772 r. na ziemiach Rzeczypospolitej były coraz bardziej jednoznaczne. Nie dziwi więc, że choć poezja polityczna schyłku konfederacji barskiej przynosiła w 1772 r. pesymistyczne obrazy kraju niszczonego wojną domową i prześladowanego przez „sąsiada”, to jednak nie ujawniała się w niej świadomość bliskiego rozbioru, czy wyraźnie rozbiorowa perspektywa wydarzeń. To samo dotyczy zresztą niektórych utworów powstałych w kręgu "Zabaw Przyjemnych i Pożytecznych"3 (dalej: ZPP), zawierających enigmatyczne i pod tym względem wieloznaczne ujęcia klęsk i nieszczęść ojczyzny.

W poezji z 1772 r. jako utwór reprezentujący pierwszą grupę odwołań do czasów barskich wyróżnia się przypisywany niekiedy A. Naruszewiczowi ${ }^{4}$ wiersz Na niszczenie ojczyzny przez rewolucję. Został tu przedstawiony bilans konfederacji barskiej - rozliczne zniszczenia oraz klęski kraju i narodu spowodowane długotrwałą wojną: „nędzna bieda”, „trudy i męka” mieszkańców, których dostatki zdobyte „z potem, z krwawą pracą” uległy zatracie oraz krew i śmierć „niewinnych ofiar" ${ }^{\circ}$. Wyrażony tu został także protest przeciw ingerencji w wewnętrzne sprawy Rzeczypospolitej obcych monarchów, narzucających prawa niesprawiedliwe i niezgodne z wolą narodu. Można to traktować przede wszystkim jako potępienie nacisku na przyjęcie praw dla różnowierców i gwarancji rosyjskiej, ale - być może — także jako moralną ocenę rozbiorowego czynu zaborców. Utwór powstał zapewne krótko przed petersburską konwencją z 5 VIII 1772 r. lub tuż po jej ogłoszeniu. Opisana w nim sytuacja Polski może być egzemplifikacją sytuacji kraju dotkniętego polityką roszczeniową, nie cofającą się przed brutalnym ugruntowaniem wpływów na drodze przemocy i wojny lub także - na

\footnotetext{
I Wskazują na to m.in. J. Michalski (Schylek konfederacji barskiej, Wrocław 1970, s. 45-46) i J. Platt (Eoyko, Naruszewicz i inni. Sprawa odpowiedzi potencjom zaborczym, [w:] Miscellanea z doby Ośviecenia 4, Wrocław 1973, s. 189, Archiwum Literackie, t. XVIII; wynika to również z opublikowanych przez E. Mottaza listów (Stanistaw Poniatowski i Maurycy Glayre. Korespondencja dotyczqca rozbiorów Polski, t. 1, Warszawa 1901, s. 55-58).

${ }^{2}$ Zob. np. wiersz Prosopophoeia Lechiae lamentantis super suo internu (Literatura barska (Antologia), wyd. II zup. zmien., oprac. J. Maciejewski, Wroclaw 1976, BN I 108 - dalej: M - s. 379-380).

${ }^{3} \mathrm{~Np}$. Ody do pokoju J. E. Minasowicza z kwietnia 1772 r. i ody J. Albertrandiego O nadziei z przełomu maja i czerwca t. r.

+ Zob. E. Rabowicz, Okolicznościowa literatura polityczna, [w:] Slownik literatury polskiego Oświecenia, red. T. Kostkiewiczowa, Wrocław 1977, s. 408. Tu także badacz sygnalizuje możliwość autorstwa A. Naruszewicza. Warto dodać, że Naruszewicz napisał utwór o podobnej wymowie pt. Wojna niesprawiedliwa („Zabawy Przyjemne i Pożyteczne" - dalej: ZPP - 1777, t. 16 cz. 1, s. 119-122), będący parafrazajakiegoś francuskiego utworu (zob.J. W. Gomulicki, wstęp do: A. Naruszewicz, Liryki uybrane, Warszawa 1964, s. 147). Ten francuski utwór był prawdopodobnie także pierwowzorem dla autora wiersza $\mathrm{Na}$ zniszczenie Ojczyzny przez rewolucję. Przypuszczenie o zależności wiersza od francuskiego pierwowzoru potwierdza tytuł odpisu utworu w rkps. B. Jag. 888, s. 169-173: Ode sur la guerre.

${ }^{5}$ Cyt. wg: B. Wolska, Poezja polityczna czasów pienvszego rozbioru i sejmu delegacyjnego 1772-1775, Wrocław 1982, s. 40 .
} 
drodze zaboru terytorium. Sygnalizowany tu wiersz ujawnia trudności interpretacyjne w obrębie utworów z 1772 r. W każdym razie ujmuje on nieszczęścia krajowe w aspekcie „win cudzych", a pojawiający się tu ton legitymizmu sankcjonowany jest nie opieką boską, lecz oświeceniowym prawem moralnym i politycznym ( - riestety -- przekraczanym przez reprezentantów polityki siły i podboju).

Warto dodać, że utwory przedstawiające skutki wojny powstawały jeszcze w 1774 r. - już po ratyfikacji rozbioru przez sejm — jak np. elegijna Pieśn o skutkach wojny... księdza Andrzeja Dunajewskiego. Akcentowany tu stan kraju to: trawiący wszystko ogień i „gruzy, popioły, wielkie mogiły" w miejscu ludnych osad. W wierszach tych wyrażano pragnienie stabilizacji, które nie mogło być zrealizowane w nowych, groźnych warunkach panowania przemocy zaborców i kliki Adama Ponińskiego.

W drugim rodzaju odwołań barskich w poezji rozbiorowej najbardzicj charakterystyczne wydają się właśnie wiersze nieznanego bliżej księdza trynitarza A. Dunajewskiego z okolic Lwowa - „pieśni żalu” układane przez niego we wszystkich kolejnych etapach decyzji rozbiorczych i po sejmie: od 6 I 1773 r. do 16 VII 1776 r., skrupulatnie przezeń datowane (6 I, 16 V 1773, 23 X 1774, 16 VII 1776). Można je określić jako rozbiorowe pogłosy poezji barskiej. Dunajewski wyraża nastroje szlachty (używa — w każdym razie — pluralis modestiae) przechodzącej w obce poddaństwo. Krytyka rozbioru jako utraty ziem ojczystych nie odgrywa tu jednakże większej roli. Na pierwszy plan wysuwa się żal za utraconą wiarą i „złotą wolnością dziedziczną"6. Inne cechy tej poezji bliskie poezji barskiej to: wezwanie do walki orężnej w obronie tych wartości, duch bojowy, ton heroicznego poświęcenia życia oraz odwoływanie się do męstwa rycerskich „cnych Polaków”. Autor krytykuje tu też gnuśna niechęć do obrony wiary i „złotej wolności”7. Rzuca to swoiste światlo na źródła koncepcji „win własnych" narodu w tych wypadkach, gdzie rodzi się ona z tradycjonalizmu. Obracamy się tu w kręgu idei ruchu barskiego, w nowych warunkach politycznych zupelnie niepodatnych na modyfikacje. Ponieważ Dunajewski przemawia w imieniu tych, którzy mieli przejść pod obce panowanie, akcentuje ich oddanie w niewolę przez współbraci. Tej perspektywie przeciwstawia mit rycerskich przodków oraz hołd dla tych, którzy zginęli podczas konfederacji barskiej. Pamięć o nich ma pobudzić do obrony wiary i wolności nie tyle ze względu na skuteczność walki zbrojnej (autor pisze wszak: „mając dość obrony zawodów”8), co w przekonaniu, że jest ona miernikiem polskiej cnoty i wyróżnikiem szlachectwa. Ożywianie mitów rycerskiej walki zbrojnej, powszechnych w latach konfederackich, miało tuż po klęsce ruchu barskiego znaczenie już tylko honorowe i było zabiegiem dość jałowym:

6 Jak w pieśni „złożonej dnia 6 stycznia $1773[\ldots] ”$.

7 W pieśni „złożonej 16 maja 1773 [...]”.

${ }^{8}$ W tej samej pieśni - ten i dalsze cyt. wg: B. Wolska, op. cit., s. 64-65. 
Kto zgubionej Matce nie poda ratunku,

Chyba nie ma w sobie polskiej krwie szacunku

Ani szlacheckiego zaszczytu.

[...]

A jeżeli chcemy sławy nabyć wiecznie,

25 Przestrzegajmyż Polski ochrony.

Tak świat będzie wiedział wśrzód świetnego słońca,

Że Polak wolności i wiary obrońca,

Krew chce wylać dla swej ojczyzny.

Cytowany utwór jest typowym przejawem tzw. myślenia życzeniowego przy niczym ni umotywowanym milczącym założeniu, że po wieloletnich wyniszczających walkach kraj staı jeszcze na obronę przed rozbiorem. Nadaje to pieśniom Dunajewskiego piętno peryferyjnej „zaściankowej” mitomanii. Należy jednak zauważyć, że kult rycerskich przodków i hołd dl: poległych barzan zostały tu przywołane dla tym silniejszego potępienia zgody na rozbió a bezsilny gniew, którym autor kwitował (np. w pieśni z maja 1773 r.) poczynania delegacj i sejmu oraz presję zaborców, świadczył o dystansie wobec nie przesądzonej jeszcze katastrof

Po ratyfikacji traktatów rozbiorowych przez sejm (co nastąpiło 30 IX 1773 r.), gd nastąpiło przekształcenie rozbioru jako konkretu politycznego w konkret prawny, wyże omówione motywy tematyczne ustępują motywom, świadczącym o dewocyjnej wierz Dunajewskiego w działanie Boga, doświadczającego w ten sposób grzeszny naród i o cora słabszych nadziejach, że On lub Matka Boska okażą litość Polakom. I tak w rok po ratyfikacj ksiądz Dunajewski we wspomnianej już, religijnej w tonacji Pieśni o skutkach wojny, zlożont 23 paźdz[iernika] 1774... zdobywał się już tylko na błagalną prośbę do Boga o litość na، narodem i skrócenie kary za grzechy ${ }^{9}$. Największym grzechem narodu jest wedlug nieg، „bezbożność zuchwała”. To zupełne zdanie się na Opatrzność może być sygnałem doś powszechnego wówczas poczucia biernej bezsilności, tu - dodatkwo - kontrastującegı z duchem bojowym wcześniejszych utworów Dunajewskiego.

W Pieśni o Naj[świętszej] Maryi P[annie] Królowej Polskiej... z lipca 1776 r. autor, wzoren barzan, odwołuje się do patronki kraju i do Chrystusa, prosząc tu o zemstę na licznycl bezpośrednich sprawców rozbioru („piorunów grady / Spuść na spiknionych wydziercóv gromady!”) i znów o litość nad grzesznym wprawdzie, ale i nieszczęśliwym narodem:

\footnotetext{
${ }^{9}$ Pieśń jest połączeniem i sparafrazowaniem wiersza kończącego artykuł z 89 nru „Monitora” z 7 XI 1767 [,Wszczynanie wojny, choćby dla odparcia bezprawnego gwałtu, przeciwne powszechnym interesom kraj i jego obywateli"] oraz fragmentów Ody do pokoju Minasowicza opublikowanej w t. 5 cz. 2 ZPP, s. 225-23 Porównanie tekstów i rozważania na temat tych relacji zob. B. Wolska: op. cit., s. 84; Pienvszy rozbiór w niezna nych wierszach politycznych z lat 1772-1775, „Prace Polonistyczne”, ser. XXXVI, 1980, s. 262-264.
} 
25 Znamy, że wielkie są narodu grzechy,

Dlatego żadnej niewarte pociechy.

$[\ldots]$

Proś jednak, wielka Matko, Twego Syna,

30 Wszak nam wyjednać Twa może przyczyna:

Niech swej karzącej już uchyli ręki,

Bo lat dwanaście jak to cierpim męki ${ }^{10}$.

Jak widać, w tej suplice do Matki Boskiej, będącej osobliwą trawestacji żałobnej pieśni Salve Regina, autor rozpoznany przez nas jako niewątpliwy sympatyk ruchu barskiego nie omieszkał zaznaczyć, że rozbiór jest ostatnim ogniwem ciągu klęsk rozpoczętego wstąpieniem na tron Stanisława Augusta. Katolicki prowidencjalizm jest u niego (jak u wielu autorów literatury barskiej) tym punktem światopoglądu, w którym skupiają się resentymenty. Jest to wyraźny przejaw związków z ideologią barską w pewnych jej aspektach.

O świadomości politycznej autora omawianych utworów świadczy i to, że będąc tak bardzo zaabsorbowany wiarą i złotą wolnością, nie widzi żadnej różnicy między stosunkami w ocalałej części kraju a ziemiami zabranymi. Wyraża więc żal z powodu utraty uprzywilejowanej sytuacji szlachty i wiary rzymskokatolickiej — jak to ujął — we wszystkich czterech częściach kraju:

Na cztery części Polska jest rozpruta,

W nich wiara, wolność srodze jest nadpsuta.

Trudno chyba było ukazać partykularyzm szlachecki czasów rozbiorowych w bardziej dewocyjnym świetle niż w tym utworze duchownego z okolic Lwowa (co kontrastuje np. z rozległością spojrzenia na sprawę rozbioru Józef Koblańskiego, jezuickiego intelektualisty związanego z tymi samymi stronami).

Wychodząc już poza utwory księdza Dunajewskiego, chciałabym wspomnieć tu jeszcze o anonimowym utworze pt. Duma slachcica kordonem podziału polskiego obwieszczonego, który jest jednym z czterech wierszy stanowiących bezpośrednią reakcję poetycką na ratyfikację rozbioru (obok Pieśni dziada sokalskiego Franciszka Karpińskiego, Nieszczęsliwej dla Polaków jesieni 1773 Koblańskiego i przeróbki utworu barskiego pt. Lament Orła Polskiego nad upadkiem ojczyzny). Poratyfikacyjny osąd rozbioru w tej dumie zdradza bowiem związki ze stylistyką i ideologią poezji barskiej, zwłaszcza w sposobie wyrażania niechęci do „lutrów”, „kalwinów” i Moskali. Jest to znowu głos pochodzący z ziem zabranych. Autor stylem antiquo modo, dosadnie i z pewną satyryczną przesadą ukazuje tu konsekwencje ustawy ratyfikacyjnej: zmianę narodowości, rządu i religii. Oto znaczący fragment:

${ }^{10}$ Cyt. fragm. Pieśni o Naj[świętszej] Maryi P[annie] Królowej Polskiej... wg: B. Wolska, Poezja polityczna czasów pienwszego rozbioru..., s. 89. 
Na sejmie teraźniejszym nasi dobrodzieje

Poddają nas w poddaństwo, nasi delegaci,

W pludry nas przystrajają obnażywszy z gaci.

Kto dotąd był w swobodzie ślachcicem Polakiem,

25 Już przez was musi stać się albo Austryjakiem,

Lub luterskim, kawlińskim Prusakiem, lub z żalem

Straty wolności w jarzmie jęczącym Moskalem ${ }^{11}$.

Miarę upokorzenia polskiej szlachty ma oddać oburzający autora paralelizm tej sytuacji z położeniem Żyda, który czyni akt wiary pod groźbą obucha.

W kolejnej grupie odwołań — publikacji i parafraz tekstów barskich — należy wspomnieć o wierszu Wacława Rzewuskiego Do kochanej ojczyzny, poprzedzającym pisane w niewoli rosyjskiej Psalmy pokutne. Mimo iż był on wywołany sytuacją kraju w czasach konfederacji barskiej, wydany został wraz z psalmami w pierwszych miesiącach 1773 r. (w Wilnie) i zyskał popularność zaświadczoną przedrukami (Lwów, Lublin, Warszawa) i licznymi odpisami rękopiśmiennymi. Ówczesnym nastrojom odpowiadała intencja tego utworu, który nawoływał do pokuty ,w okropnych czasach, w pośrodku dni smutnych” oraz zarysowywał nadzieję odmiany sytuacji ojczyzny na drodze ufnej wiary w łaskę Boską ${ }^{12}$.

Parafrazą barskiego utworu pt. Lament Orła Polskiego (inc.: „Ach! kto da oczom moim przezroczystej wody") okazuje się poratyfikacyjny Lament Orła Polskiego nad upadkiem ojczyzny (inc.: "Jakąż nutą mam nucić te czasu zawody"). Lament ten był - jak wspomniałam jedną z czterech ww. bezpośrednich reakcji na legalizację rozbioru w sejmie.

Orzeł (Orzeł Polski, Orzeł sarmacki) jako wyobrażenie alegoryczne Rzeczypospolitej pojawia się marginesowo w kilku tekstach opublikowanych w antologiach poezji barskiej ${ }^{13}$. Jako podmiot zaś Orzeł Polski występuje w dwóch tekstach wydrukwoanych w $\mathrm{K}^{14}$. W porównaniu z literaturą pierwszej połowy XVIII w., w której figurą Orła posługiwano się dość rzadko $^{15}$, oznacza to intensyfikację jej użycia w czasach barskich (zważywszy, że jest to okres zaledwie kilkuletni). Lecz analiza odpowiednich tekstów barskich wskazuje, że nie jest to wyobrażenie państwowości, które wznosiłoby się ponad pojęcia tradycyjnie rozumianej wiary i wolności. Atrybutem potęgi Orła i obiektem jego starań są tu bowiem najczęściej „wiara”

"Op. cit., s. 82.

12 Dokładna lokalizacja i zawartość edycji zob. Bibliografia literatury polskiej. Nowy Korbut, Ośuiecenie, t. 3 (6), Warszawa 1971, s. 140.

${ }_{13}$ Poezja barska, wstęp i oprac. K. Kolbuszewski, Kraków 1928, BN I 108 (dalej: K) oraz M.

14 W Lamencie Otta Polskiego (K, s. 127-129) i w Alarum do ratowania Ojczyzny (K, s. 139-143).

15 P. Buchwald-Pelcowa (Satyra czasóu' saskich, Wrocław 1969) odnotowuje też antecedencje występujących w satyrze tego okresu motywów i omawia tylko kilka utworów, w których występuje figura Orła. W sporządzonej przez J. Nowaka-Dłużewskiego Bibliografii staropolskiej okolicznościowej poezji politycznej (XVI-XVIII w.). Warszawa 1964 znajdujemy kilka utworów tego typu, też dopiero w czasach saskich (w okresie panowania Augusta II). 
i „wolnośç”, a ich uszczerbki - powodem skarg i lamentów. Podobnie zresztą jest w poezji czasów pierwszego rozbioru, co może być sygnałem ciaggej popularności w tym zakresie ujęć barskich i ich atrakcyjności.

Spośród różnych - bardziej odległych - nawiązań tego rodzaju sygnalizowany tu Lament Orła Polskiego nad upadkiem ojczyzny jest parafrazą odznaczającą sią dużą zależnością od barskiego pierwowzoru (który traktowany jest niekiedy — niesłusznie - jako tekst rozbiorowy ${ }^{16}$ ). Być może obydwa utwory są tekstami tego samego autora - wcześniejszym i późniejszym. Wiele tu stylistycznych i myślowych stereotypów poezji barskiej. Wszystko przesłaniają żale nad utratą wolności i wiary, rozumianych jako najważniejsze „prawa ojczyste” ("Wiara, wolność odjęte, co miały me szpony”). Pojawia się oskarżenie Warszawy, w której „najwolniejsze prawo” szlachty upadło oraz niechęć do króla i „bękartów krajowych”, współdziałających z zaborcami. Nowe elementy sytuacji charakteryzujące stan okrojonej ojczyzny są tu jednak przytłumione przez obrazy kraju doświadczonego utratą wolności i wiary. Zwłaszcza sprawa wiary wysuwa się na plan pierwszy, tak jakby w świadomości autora wraz z klęską konfederacji barskej i z rozbiorem upadła ostatecznie nadzieja na zmianę ustawy o innowiercach. Para alegorycznych przedstawień Polski i wolności z lamentu barskiego zostaje przekształcona w równoważną parę wolności i wiary. Barokowy konceptyzm całego ujęcia służy więc zaakcentowaniu szczególnej rangi wiary jako wartości najwyższej i atrybutu potęgi kraju:

Polska pierścień, a wolność dyjament w pierścieniu,

Polska ogród, lilije wolność w ogrodzeniu,

Polska niebo, a wolność z słońcem jednej pary,

40 Polska okręt, a wolność w okręcie towary.

I cóż teraz po niebie, gdy słońce w zaćmieniu?

Gdy dyjament skruszony, cóż mi po pierścieniu?

Gdy lilije zwiędniały, cóż mi po ogrodzie?

$\mathrm{Na}$ co okręt, gdy skarby zatonęły w wodzie?

(Lament barski ${ }^{17}$ )

35 Wolność ogród, a wiara szczep w tym ogrodzeniu,

Wolność pierścień, a wiara dyjament w pierścieniu;

Wolność portem, żeglugą wiara, równe pary,

Wolność okręt, a wiara w okręcie towary.

[...]

45 Lecz co mi po fatydze, co po ogrodzeniu?

${ }^{16}$ Przez W. Włocha w Polskiej elegii patriotycznej w epoce rozbiorótv, Kraków 1916, s. 7-8 (omówienie), s. 100-102 (tekst). Argumenty przeciwko takiemu przypisaniu: B. Wolska, op. cit., s. 113-114.

${ }^{17}$ Cyt. wg: B. Wolska, op. cit., s. 114 - na podst. rkpsu B. Jag. 2794, s. 369-371. 
Gdy dyjament skruszony, co mi po pierścieniu?

Gdy szczepy wyrąbane, co mi po ogrodzie?

$\mathrm{Na}$ co okręt, gdy towar zatopiony w wodzie?

$\left(\right.$ Lament rozbiorowy ${ }^{18}$ )

W Lamencie Orta Polskiego nad upadkiem ojczyzny (jak i w innych wierszach z czasów rozbioru, które wykazują bliskie pokrewieństwo z poezją barską) widać więc ogromne przywiązanie do hołubionych wartości i powtarzanych od lat haseł oraz ich frazeologiczno-stylistycznych ujęć. Autorom tych utworów właściwa jest pewna niemożność wyjścia poza urobione już obiegowe schematy, a w związku z tym — nieumiejętność wyrażania spraw aktualnych w sposób bardziej adekwatny w stosunku do nowych okoliczności politycznych. Działo się tak być może dlatego, że klęskę konfederacji barskiej opłakiwali oni wraz z rozbiorem, który dla wielu zwiastował ostateczny jakoby upadek wartości, o które konfederacja biła się i upominała. Nie może to dziwić, zwłaszcza w świetle rozbiorowych deklaracji zaborców, atakujących konfederację barską i w ogóle anarchię polską, oraz w świetle ich not żądających zwołania sejmu, który zalegalizowałby rozbiór i uporządkował wewnętrzne sprawy kraju. Dopiero znacznie później okazało sią, że mocarstwa rozbiorcze nie miały zamiaru wprowadzać radykalnych zmian w formie rządu, czego ludzie spod znaku barskiego powszechnie się obawiali. Podane przez zaborców i przyjęte prawa kardynalne uznawały Polskę (oczywiście, w nowych granicach) krajem republikańskim i wolnym, gwarantowały liberum veto i wolną elekcję, zaś ustawy dotyczące dysydentów uznawały wiarę rzymskokatolicką za panującą, a prawa innowierców narzucone w 1768 r. znacznie ograniczały.

Autorzy utworów, w których występowały echa barskie, byli w czasie rozbioru szczególnie podatni na propagandę Generalności, wyolbrzymiającą możliwość wystąpienia Turcji w sprawie Polski. Uwidocznia to także lament rozbiorowy, w którym pojawia się konsolacyjna przepowiednia o mającym niebawem nastąpić rozdźwięku między zaborcami. Zostaje to przedstawione jako walka między trzema Czarnymi Orłami (,wkrótce to nastąpi, iz trzy Orły Czarne [...] / Spróbują między sobą w piersiach mocnych kości") i powiązane ze spodziewaną interwencją Trucji.

Czwarty rodzaj nawiązań do czasów konfederacji barskiej występuje głównie w poetyckich reakcjach na powrót senatorów z zesłania, co nastąpiło wiosną 1773 r. — przed sejmem. Należy jednak zaznaczyć, że towarzyszące powrotowi bohaterów poezji barskiej (a więc w jej ujęciu: męczenników sprawy narodowej i gorliwych obrońców wiary i wolności) utwory okolicznościowej poezji politycznej w różny sposób interpretowały rangę tego wydarzenia, różniły się też niejednokrotnie stosunkiem do idei ruchu barskiego.

\footnotetext{
${ }^{18}$ Cyt. wg: W. Włoch, op. cit., s. 98-100, na podst. nie istniejącego dziś rkpsu ówczesnej B. Cesarsk.
} w Petersburgu Pol. XIV, fol. 11. 
Spośród dziesięciu znanych mi utworów powstałych z tej okazji (lub nawiązujących do niej nieco później) trzy poświęcono biskupowi kijowskiemu Józefowi Andrzejowi Załuskiemu (w tym dwa także w wersji łacińskiej) trzy wszystkim uwolnionym, po dwa zaś biskupowi krakowskiemu Kajetanowi Sołtykowi (łaciński i polski) i Sewerynowi Rzewuskiemu (jako staroście dolińskiemu i w 1774 r. — w powinszowaniu powrotu już nieco spóźnionym jako hetmanowi polnemu koronnemu). Obok twórców anonimowych ich autorami w większości są głównie duchowni: były nuncjusz Michał Anioł Durini, Michał Pałucki i Józef Epifani Minasowicz, związani z katedrą kijowską, Zygmunt Linowski - z katedrą krakowską oraz jezuita Naruszewicz. W większości tych wierszy dominuje ton apologetyczny oraz przesadny, a mało uzasadniony optymizm, zapowiadający z powrotem senatorów do kraju nadejście szczęśliwego czasu dla ojczyzny. W utworach skierowanych do Załuskiego wykorzystywano dla tych celów religijnie interpretowaną symbolikę jego herbu (Baranek Junosza), wiążąc ją z Wielkanocą i z wiosną - czasem wielkanocnej odnowy. Pojawiają się tu m.in. takie określenia wracających z niewoli: „uczony mąż”, „gorliwy pasterz”, „Wódz trzody - Baranek” (o Załuskim), „Polski ozdoba”, „obrońca wiary” (o Sołtyku), „obrońca wolności i wiary”, którego zdobi „laur męczeński” (o S. Rzewuskim). Tak honoruje się udział adresatów tych wierszy w wydarzeniach 1767 r., które doprowadziły do zawiązania konfederacji w Barze. Jednak obok sygnałów radosnego entuzjazmu, panegirycznych powinszowań oraz wyrazów hołdu, dla tych, którzy poświęcili się dla oborony wiary (zwłaszcza) i wolności, uderza ogólnikowość odwołań do sytuacji rozbioru lub ich brak. Prawie nic nie wskazuje na to, że teksty te zostały napisane tuż przed sejmem rozbiorwym, a niekiedy nawet już po legalizacji rozbioru ${ }^{19}$.

Na tym tle wyróżnia się utwór Naruszewicza Na powrót senatorów, będący zresztą prawdopodobnie odpowiedzią na tę produkcję poetycką, zwłaszcza zaś na anonimowy Wiersz radosny, który Grecy z Łacinnikami dytyrambem zowia, z okazji szczęsliwego powrotu senatorów polskich. Tak więc utwór anonima będący w jego zamierzeniu naśladowaniem $\mathrm{w}$ sensie formalnym Wiersza radosnego, który Grecy z Łacinnikami dithyrambem zowiq, z okazji zupetnego odzrowienia JKMci autorstwa Naruszewicza (opublikowanego w 1772 r. w ZPP, a związanego z porwaniem króla przez barzan) sprowokował z kolei — jak się wydaje — do odpowiedzi poetę królewskiego. Była ona rodzajem poetyckiej reprymendy danej anonimowi, który w zakończeniu swego wiersza wyrzucał nagrodzonemu specjalnym medalem prominentowi polityki władcy, że milczy w tak ważnej sprawie i przypominał mu obowiązki poety.

Obszerny „dytyramb” wykazuje wyraźne związki z ideami ruchu barskiego. Przypomina ważniejsze momenty ruchu, przynosi pochwałę walk toczonych przez konfederatów, a szcze-

\footnotetext{
${ }^{19} \mathrm{Jak}$ Wiersz $z$ powinszowaniem powrotu z pięcioletniej niewolu moskiewskiej J. W. Jmci Panu Sewerynowi Rzewuskiemu, staroście dolińskiemu, a teraz hetmanowi polnemu Korony, za przybyciem Jego do Lwowa od dobrego slugi Jego ofiarowany die 27 martii Anno d. 1774 (zob. B. Wolska, op. cit., s. 61).
} 
gólną uwagę poświęca wydarzeniom poprzedzającym konfederację. Aresztowanie i wywiezienie w głąb Rosji trzech senatorów i jednego posła traktuje jako najważniejsze $\mathrm{z}$ nich. Postawa obrońców wiary i wolności to przykład prawdziwej cnoty i poświęcenia, chwalony też przez upersonifikowaną Ojczyznę. Uwolnionych z zesłania wita ona z radością mimo nowego aktu bezprawia - zaboru, dokonanego „bez prawa, wojny, ni przyczyny dania”. Cnotliwi obrońcy Ojczyzny są dla niej bowiem zakładem przyszłej pomyślności kraju. Wspiera to nadzieja, że kara Boża dosięgnie niebawem państwa sąsiedzkie, Polsce dając „szczęśliwość po smutnej niedoli”.

Tendencja tego utworu jest zrozumiała w atmosferze czasu, gdy już pierwszy z uwolnionych - biskup Sołtyk, jechał przez polskie ziemie witany płaczem tłumów, biciem w dzwony i nadzieją ludzką" ${ }^{20}$. Nieznany autor wiersza (podobnie zresztą jak inni poeci) nie zastanawiał się w ogóle nad obowiązkiem działania, spoczywającym teraz szczególnie na tych, którzy cieszyli się tak ogromnym uznaniem w narodzie. Wystarczała mu identyfikacja z mitem, który ucieleśniali.

Inaczej Naruszewicz, który w swym utworze przeciwstawia się licznym ujęciom tego „wiersza radosnego" lub dyskutuje z nimi. Jego stanowisko różni się zdecydowanie od zasygnalizowanych wyżej apologii, choć poeta oddaje należną część uwolnionym. Sprowadza ją jednak do rozsądnych rozmiarów i obwarowuje warunkami: zasługa senatorów będzie zależeć od tego, jak wykorzystają zdobyty autorytet. Inaczej rozkłada akcenty. Nie akcentuje ich poświęcenia w obronie wiary i wolności, lecz — ogólniej — ofiarną gotowość wsparcia dla kraju: „żeście chcieli wspierać / Kraj, a dla niego i żyć, i umierać”. Przypomina czasy konfederacji jako trudne dla wszystkich, czyniąc też aluzje do porwania władcy. Dystansuje się od łatwej konsolacji i — świadom powinności poety — filozofa w sytuacji historycznej, gdy „grzmi wkoło niebo" - przedstawia grozę obecnej chwili. W końcowym agitacyjnym fragmencie nakłania senatorów do wspólnego działania „z królem i z narodem”, raz jeszcze uświadamiając widmo niewoli i przestrzegając przed skutkami absenteizmu w życiu kraju:

55 Dzielnych zamysłów skutek jest dowodem:

Fraszka być w kraju ciałem, a nie duszą.

Brońcie narodu z królem i z narodem.

Inaczej próżno głowę myśli suszą.

Bo kiedy rzeczy w tym zostaną stanie,

60 Będziecie w domach własnych mieć wygnanie ${ }^{21}$.

${ }^{20}$ M. Dernałowicz, Portret Familii, Warszawa 1974, s. 231.

${ }^{21}$ Cyt. fragm. wiersza Na powrót senatorów wg d. u. b. m. r. (1773, 4º), k. nlb. 2 (egz. w B. IBL Mich. XVIII. 2. 1151). 
Wkrótce okazało się, że powrót senatorów wzbudził rezonans silny, lecz krótkotrwały. Stackelberg posłużył się ich uwolnieniem dla złagodzenia nastrojów po ogłoszeniu konwencji petersburskiej. Oni sami zaś tylko przejściowo stali się obiektem oczekiwań mas szlacheckich i żądań ze strony obozu królewskego. Uwolnieni senatorowie, nie chcąc zbyt wiele ryzykować, mając nadszarpnięte niewolą zdrowie, a także nie ogarniając nowej sytuacji, sami skazali się na bierność, idąc w ślady większości bojkotującej sejm rozbiorowy, co - jak wiemy — doprowadziło do tego, że sejm ten opanowali ludzie niegodni i zdradzieccy.

W obrębie kolejnego bloku tematycznego okolicznościowej literatury politycznej lat 1772-1775, który skupia teksty formułujące ideologiczne uzasadnienia i uwarunkowania nowej polityki, echa konfederacji barskiej obserwujemy głównie w obrębie utworów dotyczących sprawy tzw. królobójców - uczestników zamachu na Stanisława Augusta w listopadzie $1771 \mathrm{r}$.

Sprawa „królobójców” rozpatrywana przez sąd sejmowy (od 7 VI do 28 VIII 1773 r.) była - w zasadzie - epizodem sejmu rozbiorowego, jednak odegrała ważną rolę, gdyż od sposobu jej załatwienia w znacznej mierze zależały szanse na pojednanie władcy ze społeczeństwem. Stawiała ona króla, zdążającego do concordia ordinum — zgody stanów i czyniącego pod adresem barzan pojednawcze gesty, w niezręcznej i kłopotliwej sytuacji. Poniński i jego stronnicy atakowali konfederację barską, a także zdążali do materialnego pognçbienia jej przywódców (w czym nb. przeszkadzał im król). Senat (a zwłaszcza marszałck Stanisław Lubomirski) nastawał na ukaranie zamachowców, wybitniejsi stronnicy króla w jego otoczeniu (Trembecki, Naruszewicz), surowsi od władcy w ocenie konfederacji barskiej, pragnęli przykładnej kary, nieprzejednany był też stosunek sądu sejmowego do oskarżonych. Taka postawa nie mogła liczyć na aprobatę króla, który dążył do zneutralizowania opozycji (wyzyskującej szum wokół sprawy przeciwko niemu), unikał jednoznacznego potępienia zamachowców i nie chciał uchodzić za gnębiciela barzan. W obronie oskarżonych wystąpił z mową w dniu 2 VIII 1773 r., która szybko zyskała rezonans w społeczeństwie i w poezji.

Wielu poetom mowa ta dawała sposobność do pochwały postawy króla, inni chwalili jego łaskawość z pewnym przymusem, jeszcze inni potępiali czyn zamachowców i oskarżali sam ruch, który się na zamach zdecydował (Naruszewicz, Trembecki).

Całkowite poleganie na łaskawości królewskiej występuje najczęściej w utworach poctów związanych z konfederacją barską lub sympatyzujących z ruchem. Mowa królewska umożliwiła im dokonanie pewnych przesunięć w interpretacji czynu zamachowców. Nie spotykamy tu dwudzielności król — barzanie, lecz dobry monarcha i oskarżeni o złą sprawę, którym — za przykładem władcy — powinno okazać się łaskę. Tak jest np. w wierszu Rafała Gurowskiego Na królobójców Stanisława Augusta. Pojawiają się tu też charakterystyczne nawiązania religijno-moralne: do Najwyższego Sędziego - Boga, od którego wszyscy ludzie oczekują miłosierdzia. W ten sposób aspekty polityczne sprawy najeżonej licznymi drażliwościami ulegały zatarciu. 
$\mathrm{Nb}$. wystąpienie Stanisława Augusta miało wiele akcentów religijnych i sugerowało ocenę czynu oskarżonych w kategoriach etyki religijnej, co dla załagodzenia sprawy chętnie podchwycili probarscy twórcy utworów. Ujawnia to także Wiersz o królobójcach Kuźmie i Damianie $^{22}$. Z okoliczności mowy JKMci za królobójcami..., który - jak rozpoznałem niedawno - jest utworem J. A. Załuskiego ${ }^{23}$. Autor skupia się na postawie „dobrego łotra”, Jana Kuźmy wybawcy króla, przypominającego jakoby Szawła, odmieniającego się w apostoła Pawła, oraz na postawie Stanisłwa Augusta, którego autor porównuje z kolei do św. Szczepana, proszącego Boga o odpuszczenie win swym prześladowcom. Dokonuje więc moralno-religijnej interpretacji tych postaw, nawiązując do znanej nowotestamentowej historii. Chwali bez zastrzeżeń miłosierdzie władcy i podkreśla jego autentyczną i głęboką wiarę widoczną w stosunku do swych winowajców. W takim ujęciu sprawa zamachu i wystąpienie monarchy przestawały być kwestią polityczną. Zdarzył się tylko incydent, który można było wystarczająco załagodzić w kategoriach etyki religijnej.

Wystąpienie Stanisława Augusta zostało przyjęte z zadowoleniem także przez pewnych - mniej znaczących — poetów z otoczenia króla, którzy wykazywali jednak bardziej nieustępliwy niż Gurowski czy Załuski stosunek wobec zamachowców. Chodzi przy tym nie o te reakcje poetyckie, które traktowały mową władcy tylko jako pretekst do propagandy polityki Stanisława Augusta moralnie wyższej od polityki barzan, lecz o wiersze będące sygnałem autentycznej akceptacji drogi pojednania w imię konsolidacji podzielonego narodu. Były one publikowane w ZPP anonimowo (np. $W$ tejże materii, inc.: „Co to za widok, świetcie zadziwiony”) lub opatrzone kryptonimami ${ }^{24}$, jak S. N. K. - kadet Stanisław Niemcewicz (Z okazji mouy królewskiej..., inc.: „Królu, dotąd z wielkimi w cnotach porównany”). Bezwarunkowej aprobacie szczerej wspaniałomyślności monarchy towarzyszylo tu wprawdzie potępienie czynu „królobójców”, jednak z pominięciem jakiejkolwiek oceny ruchu barskiego. Ich autorzy potrafili więc docenić polityczną możliwość podreperowania pozycji władcy, lecz jednocześnie (a może przede wszystkim) szansę jego pojednania z narodem. Ważniejszy niż odwet na barzanach był dla nich pożądany stan kraju oraz tworzone przez Stanisława Augusta warunki sojuszu, a tym samym i współdziałania obywateli z królem, jak o tym świadczy też na tych samych łamach utwór Mateusza Czarnka pt. Do wdzięczności, z okazji

\footnotetext{
${ }^{22}$ Damian to Robert Damiens, sprawca głośnego zamachu na Ludwika XV w 1757 r., któremu poświęcona jest znaczna część wiersza, stanowiąca jakby wstęp do oceny polskiej sprawy „królobójstwa”.

${ }^{23}$ Dzięki informacji E. Aleksandrowskiej o próbach przygotowania przez Minasowicza łacińskiego przekładu utworu (Taż, Józef Epifani Minasowicz, [w:] Pisarze polskiego Oświecenia, pod red. T. Kostkiewiczowej i Z. Golińskiego, t. 1, Warszawa 1992, s. 197) oraz po skonfrontowaniu faktów z życia biskupa kijowskiego i realiów przedstawionych w utworze. Zob. też B. Wolska (rec. ww. pozycji), „Pamiętnik Literacki” 1994, z. 3, s. 214.

${ }_{24}$ Rozwiązanymi przez Aleksandrowską: w książce „Zabawy Przyjemne i Pożyteczne” 1770-1777. Monografia bibliograficzna, Wrocław 1959 lub drogą informacji przekazanej w recenzji mojej książki Poezja polityczna czasów pierwszego rozbioru...
} 
moury Jego Królewskiej Mości... Wiersz ten podkreślał rangę wdzięczności jako cnoty społecznej, spajającej rozbity naród:

Niech tyle wdzięcznych w kraju, co obywateli

Będzie: w całości naród będziemy widzieli ${ }^{25}$.

Była to wskazówka przejęta z mowy króla, który swą wdzięczność wobec Kuźmy-Kosińskiego potraktował jako podstawę energicznej obrony oskarżonego.

Byli też poeci, jak Kajetan Kościałkowski, autor i wydawca prokrólewskiego czasopisma „Muza Ukryta pod Znakiem Herbu Syrokomli”, którzy na dobre zaaprobowali postawę władcy dopiero po wykonaniu wyroku na zamachowców (Walentym Łukawskim, Janie Cybulskim, 10 IX 1773 r.), będących w zasięgu polskiego prawa (dzięki Stanisławowi Augustowi udało się ocalić tylko Kuźmę). Okaże to wewnętrzna dynamika jego utworów. Surowa kara potraktowna jest jako słuszna rehabilitacja Polaków w oczach innych narodów (Wiersz do Eukawskiego królobójcy... i nadgrobek Cybulskiemu królobójcy...). Gdy inni poeci wymownie milczeli, list Kościałkowskiego adresowany do „królobójców” (List. najszkaradniejszym i najniegodziwszym królobójcom... oddać w srogich ziemi jaskiniach) i zwłaszcza ich odpowiedź z zaświatów (Respons od królobójców...) ukazywały straszliwe męczarnie w podziemiu Plutona, a jednocześnie dyskontowały wybaczającą postawę monarchy, dzięki której jakoby sędziowie mitologicznego podziemia wymierzyli duszom straconych zamachowców mniejszą - niemniej surową - karę. Utwory te odzwierciedlają więc nie tyle skrywane tęsknoty absolutystyczne, charakterystyczne dla innych poetów królewskich, co przeświadczenie o konieczności rozliczenia barzan i opozycjonistów Stanisława Augusta, nie poddających się prawowitej władzy ze szkodą ogółu.

W trzecim bloku tematycznym obejmującym życie polityczne czasów sejmu delegacyjnego pewne echa barskie odnajdujemy w grupie ogólnych ocen sejmu i społeczeństwa, np. w satyrycznym dopełnieniu Hymnu do mitości ojczyzny Krasickiego, które jest świadectwem zrozumiałych w kontekście ówczesnych wydarzeń, a odżywających na nowo niechęci prowincji do Warszawy. Tutaj lokalizowano przemoc i pole działania „podłych wyrodków”, tlumiących prawdziwy patritoyzm, w milczącym założeniu, że ogół był zacny i pokrzywdzony.

W grupie pamfletów na aktywistów sejmowych probarskie nastroje są silniejsze, zwłaszcza porównaniach warszawskiej konfederacji rozbiorowej i konfederacji barskiej. Bodaj wyjątkowo pojawia się tu krytyka wszelkich konfederacji, działających „pod hasłem swobody” na zgubę kraju, co wyraźnie godziło także w konfederację barską. Takie stanowisko wyraża autor pamfletu pt. Patriota $w$ źóttym kontuszu:

${ }^{25}$ Cyt. wg ZPP, t. 8, cz. 2, s. 223-228. 
Nie grunt serca, lecz same odmieniamy szaty.

A cóz kiedy zrobily te konfederaty?

Każdy związek w inne są mundury przystrajał, Moskal mu dawał sukno, a Prusak je krajał,

A łudząc, zwodząc, nęcąc, pod hasłem swobody

Skroił kurtę ojczyźnie $z$ ustawicznej mody ${ }^{26}$

Głównym celem ataku jest tu konfederacja warszawska i jej przywódcy, zaś globalne zakwestionowanie konfederacji, jednego z podstawowych przywilejów ustrojowych szlachty, świadczy o związkach autora $z$ obozem reform.

Echa barskie widać w pamfletowych reakcjach na otworzenie w 1775 r. pod koniec sejmu listy nagród „zasłużonym ojczyźnie”. W szyderczej odpowiedzi na zgłaszane propozycje nagród pt. Projekt nadgrody rozrzucony 1775 [roku] $w$ Warszawie otrzymujemy przegląd nagród à rebours - szubienicy i kaźni dla członków delegacji. Wśród nich został wymieniony „książę na Barze" - Marcin Lubomirski, niedawny działacz konfederacji barskiej współpracujący z Ponińskim i zaborcami za cenę zdjęcia sekwestru ze swych dóbr. Otrzymał on wtedy 500 tys. złp. z funduszy pojezuickich i potwierdzenie dziedzicznego posiadania Baru ${ }^{27}$. Opinia publiczna nie mogla mu tego wybaczyć, jak o tym świadczy zapowiedź szubienicy:

Dla Biskupa $z$ Wilna -

Szubienica nieomylna.

Księciu z Rydzyna -

Tytuł skurwego syna.

Księcia na Barze -

Z Wileńskim w parze 28 .

W prozatorskiej Suplice od sukcesorów Gonty i Żelaźniaka podanej królowi, która była persyflażową prośbą do Stanisława Augusta o obmyślenie nagrody także dla potomków krwawego powstania na Ukrainie w czasach konfederacji barskiej pojawiają się poważne zarzuty wobec konfederacji warszawskiej oraz wobec króla - jakoby promotora Komisji Rozdawniczej, hojnego inicjatora nadań, nagród, pensji dla oddanych sobie ludzi. Zarzuty wobec władcy są tu więc tyleż wynikiem niechęci i zadawnionych uprzedzeń, co i dezorientacji autora najprawdopodobniej byłego barzanina. Zwraca też uwagę wściekle pogardliwa paralela przywódców ukraińskiego buntu z 1768 r. i przywódców rozbiorowej konfederacji.

${ }^{26}$ Cyt. wg rkpsu B. PAN Kr. 292, s. 188-189.

${ }^{27}$ Zob. biogram J. M. Lubomirskiego autorstwa W. Szczygielskiego: Polski stownik biograficzny, t. 18, Wrocław 1973, s. 34-38.

${ }^{28}$ Cyt. wg rkpsu B. PAN Kr. 322, poz. 121, k. 254 r. 
W innym pamflecie prozatorskim z 1775 r. pt. Mowa Puhaczowa miana do pospólstwa... najprawdopodobnicj ten sam anonimowy autor kontynuuje paralele, tym razem między poczynaniami marszałka warszawskiej konfederacji i przywódcy niedawnego powstania chłopskiego w Rosji. Dochodzi tu nawet do wywyższenia Pugaczowa (podobnie jak w poprzednim utworze - Gonty), który jako „poczciwy konfederat”, świadom zohydzenia przez sejmową konfederację imienia konfederata, woli przyjąć miano „rebelizanta”. Ukazano tu więc nie tylko naganne cechy konfederacji skleconej przez Ponińskiego, ale i potraktowano je jako zaprzeczenie samej idei. Chodziło tu o oczyszczenie pojęcia konfederacji, a więc i konfederacji barskiej.

Autorzy dwóch kolejnych, bogatych w argumentację dialogowych pamfletów prozą, powstałych już po sejmie (Spacer na Faworach, przerobiony rok później - w 1776 r. - na Rozmowę ciekawe intrygi odkrywająca...) odsłaniają rozmaite zdzierstwa i matactwa Ponińskiego oraz jego wspólników, m.in. grabież kosztowności kościelnych w czasie konfederacji barskiej (ksiądz paulin A. Wargawski vel Wargacki, J. Bierzyński), jak i podczas sejmu delegacyjnego (Poniński, A. S. Młodziejowski) nieuczciwe nabywanie majętności działaczy barskich (wyrobienie przez J. Rychłowskiego dziedzictwa na dobra zabrane M. Pułaskiej, starościnie wareckiej). Dobrze zorientowani w pokrętnych biografiach członków delegacji autorzy tych utworów wywodzą się na pewno z grona barzan lub sympatyków ruchu barskiego. Dlatego też niektórych uczestników dialogu (np. Bierzyńskiego, w czasach barskich marszałka sieradzkiego, pod koniec konfederacji współpracującego $z$ ambasadą rosyjską 29 , księdza Wargawskiego czy Francuza d'Argent Cour) ukazują jako zdrajców konfederacji, szukających w czasach wojny domowej przede wszystkim zysku i własnych korzyści. Towarzyszy temu oburzenie, że ludzie tego pokroju, polityczni awanturnicy „czernili sławę poczciwych konfederatów” i prowadząc łupieżczą działalność „pod tytułem świętych myśli konfederacji za wiarę i wolność” przyczynili się do powstania określenia: „titulo” — konfederat, „vulgo" — rabuś.

Zasygnalizowane powyżej utwory ujawniają — u schyłku sejmu delegacyjnego i po jego ukończeniu —że potępieniu konfederacji warszawskiej wciąż jeszcze towarzyszył sentyment dla konfederacji barskiej. Uprzedzenia i niechęć do Stanisława Augusta są przy tym sygnalizowane bardzo rzadko, co świadczy o poprawieniu wizerunku władcy w oczach ogółu. Oprócz akcentów antykrólewskich w kilku utworach wskazanych wyżej niechęć do władcy pobrzmiewa jeszcze w wierszu Apostrophe do Najjaśniejszego Króla Jmci Polskiego Stanisława Augusta (z 1775 r.):

29 Zob. biogram J. Bierzyńskiego autorstwa W. Konopczyńskiego: Polski slownik biograficzny, t. 2, Kraków 1936, s. $85-87$. 
Gdyby też z poufałych spytał się Cię który, Czemuś nie August Czwarty ni Stanisław Wtóry,

Na takie sprawicdliwe i szczere pytanie

Nic wiem, jaka by była twa odpowiedź, Panie?

Stanisław Pierwszy nic był od wszystkich uznany,

August zaś dość nierychło po chrzcie Ci jest dany.

Idzie więc zatym, kiedyś ni Wtóry, ni Czwarty,

Że Cię królem obrano jedynie na żarty ${ }^{30}$.

Jest to wobec literatury barskiej zmiana zasadnicza. W świetle pobarskiej literatury okolicznościowej widać, że polityka królewska, a także zapewne poetycka propaganda wielostronnie argumentowanej postawy moralno-politycznej Stanisława Augusta zaczęły dawać pewne wymierne efekty m.in. w postaci zarysowującego się sojuszu średniej szlachty z władcą.

Niemniej - konfederacja Ponińskiego wydawała się sprzeniewierzeniem ideałów barskich. Społeczeństwo szlacheckie miało bowiem do porównania dwie konfederacje: bezprawną, formalnie rzecz biorąc, warszawską konfederację scjmową wspieraną przez zaborców i konfederację barską, zawiązaną niejako w blasku prawa, w imię drogich szlachcie wartości, zdławioną obcymi siłami. Kiedy zaś kaźń tzw. królobójców (jak ich powszechnie określano) dała ogółowi szlacheckiemu osobliwe oczyszczenie z tego, co wydawało się największym cieniem ruchu barskiego, bohaterów Baru i ich ideały darzono tym większym sentymentem.

Okolicznościowa literatura polityczna pierwszego rozbioru traktowana sumarycznie (np. z uwzględnieniem pewnych - tu pominiętych - ważnych grup tematycznych, jak: rocznicowo-oficjalna poezja prokrólewska, czy innych pod względem ideologicznym i światopoglądowym utworów z obrębu sygnalizowanych bloków tematycznych - rozbiór, życie polityczne) zaświadcza jednak, że społeczeństwo przestaje być zdominowane przez tych, którzy ulegają skrajnościom. Pogłosy ideologii barskiej pojawiające się w tej literaturze $\mathrm{w}$ zestawieniu $\mathrm{z}$ innymi wystąpieniami poetyckimi czynią wrażenie peryferyjne. Szlachta katolicka nadal broni swej dominacji, stereotyp rozbioru - kary za grzechy jest wciąż pospolity, stosują go jednak nie tylko sami tradycjonaliści. W obozie królewskim dokonywana jest np. hierarchizacja „grzechów narodowych” w bardzo nowoczesnym duchu oświeceniowego historyzmu. Wyobrażenia alegoryczne Wiary i Wolności ustępują miejsca alegoriom nowym, doraźnie konstytuowanym. W jednym tylko przypadku (w anonimowej Rozmowie Wolności z Polskq) posłużono się personifikacją Wolności, w dodatku dla zdyskreytowania szlacheckiego pojęcia wolności i obnażenia fałszu obiegowych politycznych stereotypów

${ }^{30}$ Cyt. wg rkpsu BAN Lw. 575/III, s. 162. 
republikańskich. Natomiast na personifikację Wiary w okolicznościowej literaturze czasów pierwszego rozbioru nie natrafiamy w ogóle.

Nadzicja na Opatrzność Boską pozostaje zwyczajowa, ale rzadko oczekuje się od nicj cudu w postaci nagłej obcej interwencji lub odstąpienia zaborców od ich zamysłów. W łasce Boskiej pokłada się teraz ufność, że ocalałym dopomoże urządzić się lepiej, zwłaszcza zaś odstąpionym pozwala to żywić nadzieję, że — być możc — rozbiorcy jeszcze się z sobą skłócą. Katolicki prowidencjalizm ułatwia teraz przystosowanic się do nwoych okoliczności, a wysiłek adaptacyjny bierze na siebie średnia szlachta, skłaniająca się do poparcia zamysłów obozu królewskiego, formułującego hasło podniesienia oświaty i cywilizacji. Na tym tle ujawnia się instrumentalny stosunek do argumentacji religijnej oraz przejawy libertynizmu (nawet w grupie reakcji poetyckich na kasatę zakonu jezuitów i nic tylko wśród dworskich intelektualistów).

Społeczeństwo szlacheckie zranione wojną domową, a przede wszystkim zaszokowane utratą rozległego terytoriu, potwierdzającą upadek prestiżu ojczyzny, ucickało się nie tylko do tradycyjnych mitów, lecz podejmowało wysiłck adaptacji i przewartościowania wielu problemów, w czym duża była zasługa poetów związanych z królem, formułujących ideologiczne przesłanki nowych postaw politycznych i pragmatyczne zalecenia rządności na przyszłość. Wiele z nich skupia się w kręgu lansowanego przez literaturę ideału mądrego, oświeceniowego władcy. Król staje sią na powrót nie kwetionowanym władcą i czynnikiem normalizacji życia w kraju. Jego wysiłki zostają nagłaśniane i są zauważane.

Staje się już jasne, że położenie ocalałego terytorium po konfederacji barskiej i rozstrzygnięciach sejmu delegacyjnego zmieni się zasadniczo, a sprawy ustrojowe nabiorą odtąd decydującego znaczenia. W wielu wypowiedziach poetyckich mniej już chodzi o to, jak zakwalifikować rozbiór, bardziej zaś - jak wykorzystać wywołany nim wstrząs do przeprowadzenia koniecznych zmian ustrojowych.

Mimo tego więc, że czasy bezpośrednio pobarskie stanowiły okres w kulturze przejściowy, że jeszcze trwały w nim postawy typowe dla czasów barskich (i to w swojej autentycznej, nie wyidealizowanej później postaci), które wpływały modyfikująco na oświeceniowe inklinacje i motywacje poezji prokrólewskiej, że poeci lansujący nową mentalność polityczną i obyczajową wciąż musieli się liczyć z tradycyjnym układem odniesienia, w okresie tym obserwujemy stopniowe wypieranie dawnych schematów i stereotypów politycznych oraz propagowanie tych motywów ideologicznych (np. wzmiankowanego wyżej hasła podniesienia oświaty i cywilizacji), wokół których skupią się z czasem usiłowania reformatorskie. 